\title{
The Effects of Occupational Licensing Evidence from Detailed Business-Level Data*
}

\author{
by
}

\author{
Marek Zapletal \\ The Brattle Group
}

\section{CES 17-20 February, 2017}

The research program of the Center for Economic Studies (CES) produces a wide range of economic analyses to improve the statistical programs of the U.S. Census Bureau. Many of these analyses take the form of CES research papers. The papers have not undergone the review accorded Census Bureau publications and no endorsement should be inferred. Any opinions and conclusions expressed herein are those of the author(s) and do not necessarily represent the views of the U.S. Census Bureau. All results have been reviewed to ensure that no confidential information is disclosed. Republication in whole or part must be cleared with the authors.

To obtain information about the series, see www.census.gov/ces or contact J. David Brown, Editor, Discussion Papers, U.S. Census Bureau, Center for Economic Studies 5K034A, 4600 Silver Hill Road, Washington, DC 20233, CES.Working.Papers@census.gov. To subscribe to the series, please click here. 


\begin{abstract}
Occupational licensing regulation has increased dramatically in importance over the last several decades, currently affecting more than one thousand occupations in the United States. I use confidential U.S. Census Bureau micro-data to study the relationship between occupational licensing and key business outcomes, such as number of practitioners, prices for consumers, and practitioners' entry and exit rates. The paper sheds light on the effect of occupational licensing on industry dynamics and intensity of competition, and is the first to study the effects on providers of required occupational training. I find that occupational licensing regulation does not affect the equilibrium number of practitioners or prices of services to consumers, but reduces significantly practitioner entry and exit rates. I further find that providers of occupational licensing training, namely, schools, are larger and seem to do better, in terms of revenues and gross margins, in states with more stringent occupational licensing regulation.
\end{abstract}

Keyword: Cosmetology, Competition, Entry, Exit, Industry Dynamics, Regulation, Schools

\footnotetext{
*This research was funded in part by the Ewing Marion Kauffman Foundation. The content of this paper is solely the responsibility of Marek Zapletal. The research was conducted while the author was a Special Sworn Status researcher of the U.S. Census Bureau. Any opinions and conclusions expressed herein are those of the author and do not necessarily represent the views of the U.S. Census Bureau. All results have been reviewed to ensure that no confidential information is disclosed. National Science Foundation (ITR-0427889) support for this research at the Michigan RDC is gratefully acknowledged. I thank Francine Lafontaine, Jagadeesh Sivadasan, Jeremy Fox, Yeşim Orhun, as well as Charles Brown, Daniel Ackerberg, Jeffrey Smith, Kyle Handley, Alicia Robb, participants at the Midwest Economics Association Meeting 2012, Consortium for Competitiveness and Cooperation 2013, and University of Michigan’s Industrial Organization Lunch, and several friends for their comments and suggestions. The usual caveat applies. I also thank Morris Kleiner for providing historical cosmetology regulation data.
} 


\section{Introduction}

Occupational licensing regulation specifies requirements a practitioner must fulfill to be permitted to perform certain services. Such regulation currently governs, to varying degrees across U.S. states, more than one thousand occupations (Brinegar, 2006), and both the number of occupations and percentage of the workforce covered by such regulations have increased dramatically over the last several decades. At present, nearly thirty percent of the workforce is required to obtain some form of licensing, up from about four percent in the 1950s (Kleiner and Krueger, 2013). These, mostly state level, regulations directly affect both blue- and white-collar workers. $^{1}$

Intended to improve service quality (Shapiro, 1986), limit negative externalities (Kleiner, 2006), and reduce information asymmetries (Arrow, 1963, Akerlof, 1970, Leland, 1979), occupational licensing regulation does not necessarily improve consumer welfare because, unlike voluntary certification, it also increases barriers to entry. Theoretical models of industry dynamics based on Jovanovic (1982), Hopenhayn (1992), and Asplund and Nocke (2006) associate higher barriers to entry with reduced competition, which can harm consumers. Welfare loss is potentially especially large in industries characterized by frequently repeated purchases, limited potential for externalities, or easy-to-implement voluntary certification.

This paper makes several contributions to the literature. First, the literature on occupational licensing has largely relied on survey data that provide limited information on the number, and entry and exit patterns of, practitioners in a market, and limited the outcomes explored mostly to earnings. I combine two comprehensive U.S. Census Bureau data sets (the

\footnotetext{
${ }^{1}$ For a detailed list, see, for instance, Bianco (1993). The Institute for Justice (Carpenter et al., 2012) recently published state licensing burdens for 102 low- and moderate-income occupations.
} 
Longitudinal Business Database (LBD) and Integrated Longitudinal Business Database (ILBD)), in order to study the effect of occupational licensing on the per capita number, as well as entry and exit rates, of practitioners and thereby shed light on the effect of licensing on the intensity of competition. Second, I study the relationship between the intensity of occupational licensing and providers of the training. This relationship, which is crucial to a better understanding of the political economy of occupational licensing regulations, has been largely unexplored until now. Lastly, I study the effects of occupational licensing in the unique setting of the cosmetology industry, which provides jobs for more than a million practitioners. This industry is characterized by localized markets, relative within-industry homogeneity of occupations, substantial variation in regulation across the U.S. states, and sizable entry costs associated with licensing.

I find no evidence that more intense occupational licensing regulation affects the equilibrium number of practitioners or leads to higher prices for consumers. I do find, however, that such regulation substantially reduces practitioner entry and exit rates. That fewer practitioners seem to test their fit for the occupation may result in lower ability practitioners being able to survive in more intensely regulated markets. Lastly, the evidence suggests that providers are the clear beneficiary of more licensing, licensing intensity being associated with both larger numbers of instructors and larger producer surplus for training schools.

The paper is organized as follows. In Section 2, I briefly review the occupational licensing literature and describe the cosmetology industry. I present a theoretical framework in Section 3, describe the data in Section 4, and discuss my empirical approach and present results on practitioners in Section 5. Results on providers of occupational licensing training are reported in Section 6, and political economy and endogeneity considerations discussed in Section 7. Concluding remarks are offered in Section 8. 


\section{Background}

\subsection{Occupational Licensing}

Occupational licensing regulation limits to those who satisfy licensing requirements the number of practitioners in an occupation. Discussion of the effects of such regulation on service providers and consumers dates at least to Adam Smith (1776), who noted how practitioners like cutlers, weavers, and hatters could restrict competition by prescribing in bylaws the length of training and limits on numbers of apprentices.

Most empirical research on the effect of occupational licensing has focused on practitioner earnings. A large literature (e.g., Friedman and Kuznets, 1945, Kleiner and Kudrle, 2000, Tenn, 2001, Angrist and Guryan, 2008, Kleiner and Park, 2010, Pagliero, 2011, Kleiner and Krueger, 2013, and Thornton and Timmons, 2013) suggests that occupational licensing has a positive effect on practitioners' mean earnings. I revisit this issue in the context of cosmetology.

The limited research that has focused on the relationship between occupational licensing and number of practitioners per capita fails to find significant effects (e.g., Thornton and Weintraub (1979) for barbers, White (1980) for registered nurses, and Thornton and Timmons (2013), who find mixed evidence for massage therapists). ${ }^{2}$

Evidence on the impact of licensing on practitioner entry and exit is even more limited. Using a binary indicator for presence of licensing, Law and Kim(2005), using data for 18801930, find licensing requirements too weak to affect the net growth of practitioners in most occupations. Although mentioned by Bresnahan and Reiss (1987) as an example of local

\footnotetext{
${ }^{2}$ Evidence on the effect of licensing regulation for nurse practitioners and physician assistants on health care service utilization is als o mixed (Stange, 2012).
} 
regulations that should increase entry costs, occupational licensing regulations are not considered in their empirical analysis. The literature, however, suggests that occupational licensing reduces interstate mobility of licensed professionals (Pashigian, 1979) and depresses the rate of immigration of workers in licensed occupations (Federman et al., 2006, Peterson et al., 2013).

Although impact on quality of service is theoretically central to arguments for occupational licensing regulation, empirical evidence suggests that this relationship is weak at best. Larsen (2012) and Hotz and Xiao (2011) find mild positive effects, but most studies find either no (Kleiner and Kudrle, 2000, Angrist and Guryan, 2008) or negative (Carroll and Gaston, 1981, Kugler and Sauer, 2005) effects. The absence of differences in malpractice insurance rates between licensed and unlicensed states (Kleiner, 2006) is consistent with weak effects of licensing on quality. Data constraints preclude me from providing evidence on this question, but given the findings of the literature, this paper assumes no effect of licensing on quality.

Previous studies of the personal care industries find little effect of an hours of training licensing requirement on practitioner supply (Thornton and Weintraub, 1979), earnings (Kleiner, 2000, Timmons and Thornton, 2010), or vocational class enrollment (Klee, 2010). Only Adams et al. (2002) provide some evidence suggestive of lower quantities and higher prices of transacted services in states with more stringent requirements.

\subsection{Cosmetology}

The standard industrial classifications, such as Standard Industrial Classification (SIC) and North American Industry Classification System (NAICS), do not distinguish between cosmetologists, hairdressers, hair designers, and hair stylists. These occupations being subject to the same 
required number of hours of training in most states, I treat them as a single category and refer to them collectively as "cosmetologists.” 3

Its idiosyncrasies make cosmetology an ideal industry in which to study the effects of occupational licensing. First, licensing can impose substantial costs, especially relative to practitioner earnings, on entry to the occupation. In 2010, the average number of required hours of training was 1,599 , the median annual wage of a cosmetology employee $\$ 22,760 .{ }^{4}$ For a conservatively chosen tuition rate of $\$ 5 /$ hour, and opportunity costs of time of $\$ 7.25 /$ hour (Federal Minimum Wage), the entry costs would be $\$ 19,588,{ }^{5}$ in relative terms, 86 percent of the median practitioner's annual wage. Using a more realistic tuition rate of $\$ 10 /$ hour, the costs amount to 121 percent of the median practitioner's annual wage.

Second, licensing requirements vary considerably across states. ${ }^{6}$ Of the several dimensions of licensing requirements (e.g., presence of a practical licensing exam, differences in state reciprocity provisions, and required years of general education), I consider number of hours of training required to be the most important source of differences in costs of regulation for prospective practitioners. Cosmetology training requirements differ by as many as 1,100 hours across states (standard deviation of 254). Factoring in tuition at $\$ 10 /$ hour and opportunity costs,

\footnotetext{
${ }^{3}$ The six-digit NAICS industrial code for cosmetologists is 812112. In 2010, there were 667,277 cosmetology nonemployer businesses (Nonemployer Statistics, U.S. Census Bureau), defined as businesses with no paid employees, and 75,355 cosmetology employer establishments with 442,149 employees (County Business Patterns, U.S. Census Bureau). Barbers constitute a separate industrial category with a separate occupational licensing regulation. The barbering industry, in terms of number of practitioners, is only about one ninth the size of the cosmetology industry.

${ }^{4}$ Occupational Employment Statistics fromthe Bureau of Labor Statistics (BLS).

${ }^{5}$ Interviews with industry insiders and extensive Internet search suggest that five dollars per training hour is on the conservative end of the spectrum. More prestigious schools, such as the Aveda Institute, often charge more than ten dollars per training hour, and tuition in the Empire Education Group, the largest cosmetolo gy s chool op erator in North America, ranges between nine and twelvedollars per training hour.

${ }^{6}$ Mention of U.S. states is understood to include the District of Columbia (D.C.).
} 
this difference corresponds to as much as $\$ 18,975$, or 83 percent of a median practitioner's annual wage.

Third, the non-tradable character of the services and limited willingness of consumers to travel to have their hair cut or styled renders cosmetology markets local. This study thus benefits from a high number of localized markets, which I equate with counties. ${ }^{7}$ Whereas some papers take as their definitions of local markets small isolated town and cities (e.g., Bresnahan and Reiss, 1991) and others Component Economic Areas (e.g., Syverson, 2004), lower travel distances for consumers of personal services together with the availability of a wide set of control variables make a county-based definition of markets most suitable.

Finally, because in many industries establishments employ workers from many distinct occupations, industry-based business data often cannot be used to study regulation of a specific occupation. But in the cosmetology industry, firms employ mainly cosmetologists. Table 1 lists the main occupations in the cosmetology industry. If supervisors are considered cosmetology practitioners, more than eighty percent of individuals working in the cosmetology industry are, in fact, cosmetologists. ${ }^{8}$ Cosmetologists can thus be tracked fairly accurately in U.S. Census Bureau business data, especially if the fraction of non-cosmetologists within the cosmetology industrial category is stable across states. The high fraction of cosmetologists within the cosmetology industrial category enables me to explore the relationship between intensity of occupational licensing and such key business outcomes as the number of practitioners in a

\footnotetext{
${ }^{7}$ I use states as the relevant market definition in the analyses of occupational licen sing training because of the greater distance students are willing to travel to get trained relative to the distanceconsumers are willing to travel to get their hair cut or styled.

${ }^{8}$ Scali-Sheahan (2008) notes that data on numbers of licensed practitioners traditionally compiled by pro fessional organizations are no longer being collected. The comprehensive U.S. Census Bureau busin ess data en able me to circumvent this problem.
} 
market, their entry and exit rates, and the revenue gap between entrants and incumbents, and thereby shed light on competition, industry dynamics, and possible selection due to occupational licensing regulation.

The Economic Census of 2007 provides information on various business characteristics of the industry. Nonemployer practitioners, for instance, defined by the U.S. Census Bureau as businesses with no paid employees generated 38 percent of total cosmetology revenues of $\$ 32.2$ billion in 2007.9 In terms of legal form of organization, 98 percent of nonemployer businesses are proprietorships. With respect to employer establishments, 59 percent are corporations, 30 percent proprietorships, and 11 percent partnerships. Hair care services are responsible for 78 percent, merchandise sales for about six percent, skin-care services for five percent, and nail services for four percent of the revenues of cosmetology employer establishments. Massage and hair removal services and office space rentals account for the remaining seven percent.

\section{Theoretical Framework}

Because occupational licensing regulation increases the costs of entry, it should have a negative effect on the equilibrium number of practitioners in an industry. In states with more stringent regulation, the quantity of services provided is expected to be lower and price of services higher.

To provide intuition for the expected effect of sunk entry costs on equilibrium industry dynamics, that is, on entry and exit rates, I briefly describe a model by Backus (2012) that builds on Hopenhayn (1992) and Asplund and Nocke (2006).

\footnotetext{
${ }^{9}$ I use the Bureau of Labor Statistics' Consumer Price Index(CPI-U) to convert all variables denominated in current dollars to constant 2010 base, denoted in the tables by $(2010 \$)$.
} 
Businesses in the model are assumed to be infinitesimally small and the number of $e x$ ante identical potential entrants unlimited. Entrants pay the sunk costs of entry $S$ to become active and learn their ability $\theta_{t}$, which positively affects current period profitability $\pi_{t}$ and, over time, evolves according to a Markov process based on a cumulative distribution function $F\left(\theta_{t+1} \mid \theta_{t}\right)$. Every period, each incumbent decides, based on ability $\theta_{t}$ and intensity of competition $C_{t}$ in the market, whether to remain or exit the industry. Intensity of competition is captured by the distribution of types of active businesses. The payoff from exiting is normalized to zero.

The value function of an active business can be written recursively as,

$$
V_{t}\left(\theta_{t}, C_{t}\right)=\pi_{t}\left(\theta_{t}, C_{t}\right)+\max \left\{0, \beta \int V_{t+1}\left(\theta_{t+1}, C_{t+1}\right) d F\left(\theta_{t+1} \mid \theta_{t}\right)\right\}
$$

where $\beta$ is a discount factor. If entry is positive in equilibrium, the ex ante expected value of entering for an entrant of ability $\theta_{E}$ facing level of competition $C^{*}$ has to be equal to the sunk costs of entry,

$$
\int \beta V_{t+1}\left(\theta_{t+1}, C^{*}\right) d F\left(\theta_{t+1} \mid \theta_{E}\right)=S_{t}
$$

The exit strategy is summarized by a threshold rule that requires practitioners with ability equal to the exit threshold to be indifferent between remaining and exiting,

$$
\int V_{t+1}\left(\theta_{t+1}, C^{*}\right) d F\left(\theta_{t+1} \mid \theta^{*}\right)=0
$$

Intensity of competition is determined by the distribution of entrant types, and of incumbent types from the previous period,

$$
C_{t+1}\left(\theta_{t+1}\right)=\gamma^{*} F\left(\theta_{t+1} \mid \theta_{E}\right)+\int_{\theta^{*}}^{1} F\left(\theta_{t+1} \mid \theta_{t}\right) d C\left(\theta_{t}\right) .
$$


A stationary competitive equilibrium of this game yields an equilibrium entry $\gamma^{*}$, ability threshold $\theta^{*}$ below which incumbent businesses exit, as well as equilibrium intensity of competition $C^{*}$.

The model implies that higher sunk costs of entry result in lower entry and exit rates. ${ }^{10}$ The proof, done by Backus (2012), is conducted in two steps. First, it can be shown that higher sunk costs of entry imply a lower exit threshold. Second, entry and exit rates increase in the exit threshold. Higher sunk costs of entry thus imply lower equilibrium entry and exit rates.

\section{Data}

\subsection{Licensing Regulation}

Licensing requirements for cosmetologists have been around for decades, the first U.S. state to enact such regulation being Georgia, in 1914. By 1950, cosmetologists faced licensing requirements in 45 states (Council of State Governments, 1952). Hours of training required have been remarkably stable within states since at least the early 1980s. The median state hours requirement has been constant since that time as well, at 1,500 hours.

Because I am interested in long-run equilibrium outcomes, sunk costs of obtaining a license being irrelevant in the short run, my analyses focus on states with a stable hours requirement. I therefore consider only states in the contiguous United States with no documented change in the cosmetology training hours requirement from 1981 to $2010^{11}$ and no multiple licensing categories within cosmetology. ${ }^{12}$ The hours of training required in all U.S. states in

\footnotetext{
${ }^{10}$ Entry rate equals exit rate in equilibrium.

${ }^{11}$ These years are determined by the availability of occupational licensing regulation data.

${ }^{12}$ Because they have multiple licensing categories with differing hours requirements, I exclude Colorado, Georg ia, Idaho, Nevada, Ohio, and Wyoming. Colorado, for instance, requires cosmetologists to have 1,800 hours of training, hairstylists 1,200 hours of training.
} 
2010, and the 32 states that satisfy the aforementioned restrictions, are listed in Appendix A (and depicted as well in a map in Figure 1). ${ }^{13}$ The latter states accounted for 72.1 percent of the U.S. population in 2010 .

Occupational licensing regulation is binding for all practitioners. Some states automatically license practitioners from other states with similar licensing requirements; other states require practitioners to take a new state licensing exam. Substituting years of practice for part of the hours requirement, in states in which it is permitted, enables some migrating practitioners, especially those migrating from low to high hours training requirement states, to take the licensing exam in a new state without having to return to a training school. ${ }^{14}$

Because building a clientele base is important in this industry, moving between states to avoid stricter licensing regulation is unlikely to be common. Working unlicensed, because it is usually a misdemeanor punishable by a fine and possibly imprisonment, is also unlikely. Because they provide services to the public, cosmetologists would find it difficult to work clandestinely without the authorities or competitors noticing. ${ }^{15}$

Although the barrier occupational licensing poses to entry, because it is likely to decrease competition, might benefit practitioners by enabling them to earn more, this benefit may be offset by the costly upfront investment required to acquire a license. Schools that provide

\footnotetext{
${ }^{13}$ For robustness, I consider an extended set of states that had neither any change in the hours regulation in the 1993-2010 period nor multiple licensing categories (except for Georgia, in which cosmetology and hair stylist categories differ by only 175 hours). The 44 states are depicted in Figure 2 . The results are consistent with the results from the baseline set of 32 states.

${ }^{14}$ In Michigan, for instance, the conversion rate is sixmonths of experience for every hundred hours of training a cosmetologist lacks. Thus, an individual newly licensed in New York (1,000 hour requirement) who wants to mo ve to Michigan (1,500 hour requirement) must either make up the difference in hours by returning to a cos metology school or have practiced in New York for at least 30 months ((1,500 hrs. - 1,000 hrs.)/100 × 6 months $)$.

${ }^{15}$ In states like Texas and California, detection of unlicensed practitioners by authorities is facilitated by the availability of an online complaint form that can be filed anonymously.
} 
training, however, are likely benefit from occupational licensing because individuals who want to become licensed must be trained in an approved school. Schools benefit from higher regulation if demand for training services is inelastic with respect to the hours requirement, and profit as well from student tuition and revenues earned by students practicing during training. Currently licensed cosmetologists would likely be worse off were licensing to be relaxed as competition would likely increase.

Information on licensing requirements is from several sources. Information on cosmetology licensing requirements for 2010 is from the 2010 Endorsement Report of the National-Interstate Council of State Boards of Cosmetology as well as my own compilations based on searches of individual state statutes, e-mail exchanges, and telephone interviews with representatives of state regulation boards and cosmetology schools. Morris Kleiner provided historical cosmetology regulation data dating back to $1981 .{ }^{16}$ Information on cosmetology regulation in 1993 is from Bianco (1993). The mean of mandated training hours over the 32 states in my sample is 1,567 hours. In the regressions, I measure the training hours requirement in hundreds of hours.

\subsection{Dependent Variables - Practitioners}

My empirical analyses rely on multiple sources of data. ${ }^{17}$ The equilibrium number of practitioners per capita and their entry and exit rates are constructed from two confidential U.S. Census Bureau databases, the Longitudinal Business Database (LBD) and Integrated Longitudinal Business Database (ILBD). The LBD and ILBD provide not only more detailed information on businesses than publicly available data like the County Business Patterns and

\footnotetext{
${ }^{16}$ These data are us ed in Kleiner (2006).

${ }^{17}$ AppendixB lists all dependent variables, the level at which they vary, and the data source.
} 
Nonemployer Statistics, but also linkages of employer establishments and nonemployer businesses over time that enable me to create county-year level measures of practitioner entry and exit.

The ILBD contains annual information on geographic location and annual revenues for all private sector nonemployer businesses in the United States. ${ }^{18}$ Defined as businesses with no paid employees, nonemployer businesses accounted for 57 percent of cosmetology practitioners. I use the ILBD for 1994-2010, which is the longest uninterrupted interval currently available. The LBD provides annual information on location and employment for all private sector employer establishments in the United States ${ }^{19}$ As well as analyzing the effect of licensing only on nonemployer practitioners, I also combine the ILBD and LBD to provide evidence on all cosmetology practitioners.

I assume a single practitioner to be involved in each nonemployer business, and employer establishments to have one practicing owner (partnerships, two practicing owners) and exclusively practitioner employees. ${ }^{20}$ The number of practitioners per capita is defined as the number of practitioners in a county divided by the county's population. Table 2 shows there to be, on average, 245 cosmetology practitioners per hundred thousand people, 178 of which are nonemployers. I focus only on the 32 states with stable licensing requirements, as discussed in Section 4.1. To simplify disclosure of results from the Census Bureau, I also consider only counties that had at least one cosmetology practitioner each year during the 1995-2009 period.

\footnotetext{
${ }^{18}$ The ILBD, described in some detail by Davis et al. (2007), draws on information fromindividualand corp orate tax returns and various business surveys conducted by the U.S. Census Bureau.

${ }^{19}$ Information on the construction of the LBD can be found in Jarmin and Miranda(2002).

${ }^{20}$ To limit the influence of measurement error and outliers, I consider only establishments in which the nu mb er of employees does not exceed the 99.99th percentile number of employees and adjusted average annual rev enues are between $\$ 1,000$ and $\$ 150,000$ (2010 \$).
} 
This restriction is binding for less than two percent of counties. My sample for the county-level analyses consists of 2,055 observations (counties) per year.

As the equilibrium number of provided services is affected not only by the number of practitioners, but also by how much those practitioners work, I use the U.S. Census Bureau's publicly available American Community Survey (ACS) to investigate whether occupation licensing affects practitioners' weekly work hours (neither the ILBD nor LBD contain information on weekly hours of work). ${ }^{21}$ Table 3, which provides descriptive statistics for the individual level data from the ACS, shows cosmetology practitioners to be, on average, 41 years of age, work, on average, 33.6 hours per week, and be mostly women. Constrained by the level of detail in the ACS data, the hours of work analyses are done only at the state-year level.

Entry and exit rates, defined at the county-year level, are based on information in the ILBD and LBD. For nonemployers, entrants are practitioners whose businesses are operating in the current period but were not in the market in the previous period. Entry rates are calculated as the ratio of year $t$ number of entrants to year $t-1$ number of practitioners. I create in a similar manner a county-year count of exiters. These are practitioners whose businesses are operating in the current period but are not in the market the following period. Exit rates are calculated as the ratio of year $t$ number of exiters to year $t$ number of practitioners. Table 2 shows nonemployer entry rates to have a mean of 26.6 percent and nonemployer exit rates a mean of 23.7 percent. As expected for an industry in long-run equilibrium and predicted by the model in Section 3, the entry rates are statistically no different from the exit rates.

\footnotetext{
${ }^{21}$ I use surveys for 2000-2011, currently the longest available span. As the ACS's question on usual we ekly hours worked is asked for the year preceding the survey, my analyses span 1999-2010.
} 
For robustness, I create entry and exit rates for all, nonemployer and employer, practitioners. Entry and exit of the employer establishments is analogous to the nonemployer universe, differing only in terms of weighting by the number of practitioners in an establishment. Expansions and contractions of continuing establishments require some additional assumptions, as I do not have unique identifiers for individual practitioners within a business establishment. Expansion of an employer establishment is assumed to be covered by new practitioners, contractions due to practitioners exiting the profession. Continuing employer establishments that remain at the same employment size are assumed to retain the same practitioners, although, in fact, entering practitioners could have exactly offset exiting practitioners. Because of the additional assumptions needed because of the LBD data limitations, I use the combined nonemployer and employer measures only for robustness checks, and focus my analyses primarily on nonemployer entry and exit rates.

The entry rates I obtain are likely to be somewhat greater than measures based on new licensees. For example, the entry rate for Texas, which has been publishing data on numbers of new licensees, is about eighteen percent. I find higher rates because not all entrants are newly licensed practitioners. Exit rates are also likely to be greater than measures based on practitioners' terminal exits from a profession. Higher entry and exit rates do not pose a problem for my entry and exit analyses as long as differences between the business-based measures I use and practitioner-based measures are not correlated with the intensity of occupational licensing.

Although the information from the LBD and ILBD enables me to measure my main variables of interest, number of practitioners per capita and practitioner entry and exit rates, occupational licensing regulation, as noted earlier, is also expected to affect practitioner earnings and consumer prices. From the ILBD, I obtain gross revenues of nonemployer practitioners from 
which I calculate median nonemployer practitioner revenues for each county and year. This variable and all other variables denominated in current dollars are converted to a constant 2010 base using the Bureau of Labor Statistics' Consumer Price Index (CPI-U). The mean of median nonemployer practitioner revenues is $\$ 15,993$. This value being smaller than the median annual full-time wage of $\$ 22,760$ reported by the Occupational Employment Statistics for 2010, it would appear that many practitioners are either not able to capture enough clientele or are working part time.

For consumer prices, I generate state-year level average prices for women's cut and shampoo blow-dry from Cost of Living Index (COLI) data derived from a survey of establishments in urban areas and published by the Council for Community and Economic Research (C2ER). Table 4 shows the mean price of women's cut and shampoo blow-dry to be $\$ 30.4$, with a standard deviation of $\$ 5.5$.

To provide insight into selection of practitioners caused by occupational licensing, I use the ILBD to define a gap in nonemployer entrants' revenues as the median annual revenues of an incumbent minus the median annual revenues of an entrant within the same market. As expected, the median entrant has, on average, smaller revenues than the median incumbent, the average gap, as can be seen in Table 2, being $\$ 4,334$.

\subsection{Dependent Variables - Providers of Occupational Training}

The Economic Census for 2007 identifies 1,727 cosmetology and barber schools with 15,999 employees and revenues of more than $\$ 1.3$ billion. Eighty-three percent of these schools' revenues were generated by occupational training, seven percent by personal care services, and the remaining ten percent by merchandise sales, office space rentals, and other activities. 
The relevant market for schools being geographically larger than that for cosmetology services, and number of schools in a typical county being small, I analyze providers of occupational training at the state level. Although the NAICS industrial classification does not distinguish between cosmetology and barber schools (NAICS 611511), cosmetology schools accounted for more than 94 percent of cosmetology and barber school establishments in December 2011 according to the U.S. Department of Education Database of Accredited Postsecondary Institutions and Programs. Thus, I restrict the current analyses to the set of 32 states used in the cosmetology practitioner analyses, and consider cosmetology hours requirements to be the relevant measure of required training.

Using the LBD database and Census population data, I calculate Instructors per Capita, defined as the number of instructors in a given state divided by the state's population. All employees as well as owners of school establishments are assumed to be instructors. I assume each establishment to have one owner (partnerships, two owners). Table 5 shows there to be 4.8 cosmetology instructors per 100,000 people. Number of School Establishments, also measured at the state-year level, is, on average, 33 per state. School Establishment Size, being the median number of instructors per establishment in the state-year, is, on average, 8.9. Instructors' Median Wage, calculated from the LBD's annual payroll and number of employees per establishment, is \$23,774. Average Revenues per School Establishment is calculated from the publicly available version of the Economic Census of 2002 (EC 2002). These data include total annual training school revenues at the state level, which I divide by the number of the school establishments in the state that year. The mean is $\$ 579,054$. Average Gross Margin per School Establishment is defined as annual state training school revenues minus total payroll divided by the number of school establishments in the state that year. The mean is $\$ 383,801$. Although fairly large, this 
margin is not equal to the economic rent, as school establishments also have to cover office rent, cost of energy and materials, and the opportunity costs of the owner.

\subsection{Market Characte ristics}

Throughout my analyses, I control for a number of market-level characteristics. Campbell and Hopenhayn (2005) and Asplund and Nocke (2006) show that intensity of competition and industry turnover should increase with market size. I therefore include in all regressions yearly population levels and demographics (age, gender, and race composition) obtained from the County Population Estimates of the U.S. Census Bureau from 1995 to 2009. ${ }^{22}$ Table 2 shows the average county population to be about one hundred thousand people. County data on annual personal income per capita, which is assumed to positively affect demand for cosmetology services, are from the Regional Economic Accounts of the Bureau of Economic Analysis. Mean personal income per capita is $\$ 30,278$. County geographic area, which may affect consumer commuting distance and thus intensity of competition, and high school educational attainment data, which may affect the supply of practitioners, are from the U.S. Census Bureau State and County QuickFacts. ${ }^{23}$ County-level data on annual unemployment rates, which may influence both demand for services and supply of practitioners, are from the Local Area Unemployment Statistics of the Bureau of Labor Statistics (BLS). The unemployment rate averages 5.6 percent. In all the state-level analyses including analyses of number of hours worked, price of service, and providers of occupational training the market characteristics are included at the state level.

\footnotetext{
${ }^{22}$ In specifications that analyze the impact of licensing on the number of practitioners per capita, population is us ed only to create the dependent variable, not as a control variable. Because I include number of practitioners per cap it a in the regression as a dependent variable only after logarithmic transformation, the elasticity of population with respect to the number of practitioners is restricted to one.

${ }^{23}$ Educational attainment data from the U.S. Census Bureau State and County QuickFacts are cross-sectional; Census derives them fromthe American Community Surveys from2007-2011.
} 
To control for possible unobserved factors that may affect economic outcomes in densely populated areas and are not fully captured by population and personal income variables (e.g., higher office rent), I include in the county-level analyses a binary indicator for central counties of metropolitan statistical areas obtained from U.S. Census Bureau Metropolitan and Micropolitan Statistical Areas data. To account for the possibility that states with more stringent occupational licensing regulation may have also adopted other business regulations that might affect my analyses, I include the Small Business Survival Index (SBSI) for the year 2000 produced by the Small Business \& Entrepreneurship Council (Keating, 2000) and designed to reflect major state-level costs imposed on businesses; the greater the index, the greater the costs. In the sample, the index ranges from 24.9 (South Dakota) to 68.2 (D.C.).

\section{Econometric Specifications and Results}

The theoretical framework in Section 3 provides several predictions about the effects of occupational licensing regulation that I investigate in this section. I first test whether occupational licensing negatively affects number of practitioners per capita and quantity of services provided by examining the number of practitioners per capita and hours of work per practitioner. I next test whether prices are higher in markets with more stringent occupational licensing and, using nonemployer revenue data, also estimate whether practitioner revenues are higher in such markets. I then examine the effects of occupational licensing on entry and exit rates, which, based on the model of long-run industry dynamics described in Section 3, should be lower in markets with more stringent requirements. To provide insight into selection due to occupational licensing, I test whether entrants do better, relative to incumbents, in more regulated markets. I expect the gap in revenues between entrants who test their fit for the 
occupation and incumbents to be larger in markets with low occupational licensing requirements. ${ }^{24}$

To study the effects of occupational licensing, I rely on variation in the intensity of licensing training requirements across states. As the effect of licensing intensity cannot be identified together with state fixed effects, to mitigate concerns about omitted variable bias, my specifications include an extensive list of variables that might be both correlated with the intensity of occupational licensing regulation and affect the outcomes of interest. The specifications also include year and Census division fixed effects to account for such unobserved factors as differences in tastes across divisions and time. ${ }^{25}$

\subsection{Number of Practitioners per Capita and Usual Hours of Work}

Based on the theoretical framework in Section 3, regulation is expected to have a negative effect on number of practitioners per capita. I therefore estimate the following equation,

$$
Y_{c s t}=\alpha R_{s}+\beta X_{c s t}+\eta_{t} \times \delta_{d}+\varepsilon_{c s t}
$$

where the $c$ subscript indexes counties, the $s$ subscript states, $d$ subscript geographical divisions within the United States, and the $t$ subscript years. ${ }^{26}$ My analyses cover 2,055 counties in 32 states over 15 years. In this specification, $Y_{c s t}$ is the log of per capita number of practitioners. The natural logarithm is used to limit the impact of outliers. For the same reason, I perform a logarithmic transformation for two control variables, personal income per capita and geographic

\footnotetext{
${ }^{24}$ Based on the model in Section 3, the ability threshold $\theta^{*}$ for surviving in the market with lower sunk costs is higher.

${ }^{25}$ The U.S. Census Bureau defines nine divisions, namely, New England, Middle Atlantic, East North Central, West North Central, South Atlantic, East South Central, West South Central, Mountain, and Pacific.

${ }^{26}$ To simplify disclosure review of the results by the U.S. Census Bureau, all regression analyses are provided for 1995-2009. Year 1994 data were used to define entry rates for the year 1995 and year 2010 data to define exit rates in 2009.
} 
area. The main independent variable of interest is Regulation $\left(R_{s}\right)$, measured in hundreds of hours of training required.

The vector of control variables $\left(X_{c s t}\right)$ includes the county-year log of per capita personal income, unemployment rate, and county demographics, specifically, the gender, race, and age compositions of the population. It also contains county-level geographic area, high school education, a state-level indicator for the general business environment (SBSI index), and a binary variable for whether the observation comes from a central county of a metropolitan statistical area. To account for common unobserved factors within years and U.S. Census Bureau divisions, I include year fixed effects interacted with division fixed effects, denoted by $\eta_{t} \times \delta_{d}$. Because the outcomes of interest may be correlated across counties within a state as well as over time, standard errors are clustered at the state level.

The results in Table 6 imply no effect of intensity of licensing training on number of practitioners per capita. In the specification with year-division fixed effects (column 2), the effect of an extra one hundred hours of training requirement on number of practitioners per capita is -0.3 percent and not statistically different from zero. This finding is surprising because occupational licensing is expected to reduce the number of practitioners. At the conventional statistical significance level, however, the confidence interval allows me to detect only an effect larger than one percent. Thus, a reduction, if there is one, must be relatively small. Considering only nonemployer practitioners (column 4) yields the same conclusion.

Because the total number of hours cosmetology practitioners provide is affected by not only the number of practitioners, but also the number of hours they work, I employ the ACS data that contain information on cosmetologists' usual weekly hours. To analyze whether 
practitioners work fewer hours in states with more intense occupational licensing regulation, I estimate the following equation,

$$
Y_{i s t}=\alpha R_{s}+\beta X_{i s t}+\eta_{t}+\delta_{d}+\varepsilon_{i s t}
$$

where the $i$ subscript indexes individual practitioners, the $s$ subscript states, the $d$ subscript geographical divisions within the United States, and the $t$ subscript years. The regression is a pooled ordinary least squares (OLS). The results in Table 7 suggest that cosmetologists do not work more hours in more intensely regulated states. In the specification with year-division fixed effects (column 2), the effect of an extra one hundred hours of training requirement on the usual weekly hours of work is 0.1 percent and not statistically different from zero. The standard errors are, however, large, and at the conventional statistical significance level allow me to detect only an effect larger than 6.7 percent.

In the aggregate, the results for number of practitioners and their usual hours of work suggest, quite surprisingly, no significant effect of occupational licensing on the equilibrium quantity of services provided.

\subsection{Cons ume r Prices and Practitioner Earnings}

Occupational licensing may affect prices by increasing practitioner skill and thus improving the quality of services rendered, or by reducing competition, enabling existing providers to charge more. I do not find any effect of licensing regulation on consumer prices, as shown in Table 8. In the specification with year-division fixed effects (column 2), the effect of an extra one hundred hours of training requirement on the price of a women's cut and shampoo blow-dry is close to zero. The standard errors are, however, somewhat large, and allow me to detect, at the conventional statistical significance level, only an effect greater than 1.5 percent. The finding of 
no significant results on prices, although surprising, taken together with the foregoing finding of no effect on per capita number of practitioners, suggests that consumers may not experience negative consequences, in terms of higher prices or fewer providers, of more stringent occupational licensing.

To increase confidence in my findings on prices and hours of work, I examine the effect of licensing on median practitioner annual revenues. As I do not find effects of occupational licensing on prices of cosmetology services or cosmetology practitioners' usual hours of work, I do not expect to find any effect of occupational licensing on annual revenues. Table 9 shows that, in the specification with year-division fixed effects (column 2), the effect of an extra one hundred hours of training requirement on median practitioner revenues is small and only marginally statistically significant. Annual revenues of the median practitioner in the county are thus surely not higher in more regulated markets.

\subsection{Industry Dynamics - Entry and Exit Rates}

The model described in Section 3 assumes equilibrium entry and exit rates to be equal in a longrun equilibrium, and implies that they should be negatively related to the sunk costs of entry. I test this prediction with a specification similar to those in Section 5.1. In the entry rate specification, however, I use control variables lagged by one year, as it may be last year's market conditions that drive potential practitioners' decisions to start occupational licensing training. I estimate the following equation,

$$
Y_{c s t}=\alpha R_{s}+\beta X_{c s(t-1)}+\eta_{t} \times \delta_{d}+\varepsilon_{c s t}
$$

where, again, the $c$ subscript indexes counties, the $s$ subscript states, the $d$ subscript geographical divisions within the United States, and the $t$ subscript years. Controlling for year times division 
fixed effects in Table 10, column 2, produces entry rates smaller by half a percentage point per hundred hours of licensing requirement. This is a substantial effect, given a mean entry rate of 24.9 percent. The effect is slightly stronger when only nonemployer practitioners, for whom the constructed entry (and exit) measures have less measurement error, are considered, as discussed in Section 4. Entry rate results are robust to considering current period control variables. As expected based on the model, and as can be seen in columns 2 and 4 in the second half of the table, the effect on exit rates is similar in magnitude to the effect on entry rates. The findings on entry and exit rates are consistent with the predictions of the long-run industry dynamics model, which implies entry and exit rates lower in markets with more stringent requirements.

Overall, the evidence suggests that the effect of regulation on prices and revenues is small at best. Entrants in highly regulated markets might, however, through more training, be able to earn higher revenues than those in less regulated markets without affecting median revenues in the market.

In a last set of analyses of practitioners, I consider a specification similar to those in Section 5.1, in which the dependent variable is, however, the revenue gap between the median entrant and median incumbent nonemployer practitioner in a market. The results, reported in Table 11, suggest that entrants' revenues are greater relative to those of incumbents in states with a higher hours requirement. The gap is $\$ 182$ in annual revenues per hundred hours' difference in licensing requirement. Entering practitioners might thus still be able to recoup at least part of the cost of a higher occupational licensing requirement by being able to earn more from the start. The results are robust to considering a gap normalized by median nonemployer revenues in the market that year. 


\section{Providers of Occupational Training}

Turning to the link between the intensity of occupational licensing and outcomes for training providers, I estimate the relationship between regulation and number of instructors per capita, number of training school establishments, and median school establishment size. I use a specification similar to that used in the per capita number of practitioners' regressions and rely again on cross-state variation in the hours requirements. Observations, however, are at the stateyear instead of county-year level, as the relevant market for schools is geographically larger than that for cosmetology services and the number of schools in a typical county small.

The results, reported in Table 12, show states with more intense training requirements to have more instructors per capita. This is not surprising, given the above documented lack of a negative effect of regulation on per capita number of practitioners. If number of instructors is proportional to average required number of training hours in the sample, specifically 1,567 hours, an increase of one hundred hours in the licensing requirement corresponds to 6.4 percent increase $(100 * 100 \% / 1,567)$ in the number of instructors needed. The actual estimate with division fixed effects is 5.1 percent, which is somewhat smaller and could be explained by my finding of lower entry rates in markets with more stringent occupational licensing. As can be seen in the last column of Table 12, however, instructors in more regulated states are not better paid. The estimated coefficient is close to zero. The training requirement also does not affect number of school establishments, as can be seen in column 2 of Table 13. The standard errors are, however, somewhat large, and would enable me to detect an effect of at least 3.8 percent per hundred hours. The median size of the school establishment, in terms of number of instructors, is larger in more intensely regulated states by about 6.3 percent, as shown in column 4 of the table. 
In Table 14, I report results on the relationship between the hours training requirement and schools' revenues and gross margins, which imply that average revenues of school establishments are greater in states with more stringent licensing. Although these regressions are limited to a single year and the sample is relatively small, the estimates are large and statistically significant. ${ }^{27}$ Gross margins earned by these schools (i.e., revenues minus payroll) are also substantially larger in more stringently regulated states. When I include division fixed effects to control for tastes and other unobserved division-level differences, the effect is about twenty percent per hundred hours of training requirement, as can be seen in the last column of Table 14. Given the large magnitude of this coefficient, schools, even when their larger size (Table 13, last column) is taken into consideration, seem to do better in more regulated states. Together, these findings suggest that the benefits of occupational licensing accrue mostly to owners of schools.

\section{Political Economy and Endogeneity}

Angel (1970) cites as two of the main reasons for growth in licensing public demand for increased protection and pressure by members of occupational groups on state legislators. Stigler (1971), discussing the political economy aspects of these types of regulations, suggests that occupations in states with greater occupational size relative to the total labor force become subject to licensing requirements earlier. The capture theory of occupational licensing is supported by Pagliero (2011). Other research concludes that the political economy aspects of occupational licensing regulation affect both the timing and intensity of regulation (Wheelan, 1998, Tenn, 2001, Law and Kim, 2005).

\footnotetext{
${ }^{27}$ The sample is small because, I currently have to rely only on publicly available aggregate information from the Economic Census of 2002, which provides information for only a subset of states.
} 
One implication of the political economy view of these regulations is that reverse causality might be a concern when estimating the effects of occupational licensing. That is, occupational licensing regulation may be more stringent in states with a greater number of practitioners per capita because of their political power and desire to limit the number of future entrants.

To shed light on this question, I regress the current intensity of regulation in states with stable licensing requirements on number of practitioners per capita and fraction of urban population in the Census years 1900, 1910, 1920, and 1930. Because the historical Census did not separate the two, I include as practitioners both barbers and hairdressers. My finding that states with more practitioners per capita adopted more stringent hours requirements is shown in Specification A in Table 15. When I include division fixed effects (Specification B), however, the coefficients become smaller and statistically not significant. I also find that states with a higher number of cosmetology practitioners per capita adopt licensing regulation for the occupation sooner (Specification A, Appendix C). ${ }^{28}$ As above, with division fixed effects the coefficients become smaller and statistically not significant (Specification B, Appendix C). Altogether, the results confirm the importance of including division fixed effects in analyses of the effects of licensing regulations. However, as my analyses focus on recent years in states with stable hours requirements, the causes of behind regulation intensity, unless they persist over very long horizons, should be irrelevant.

A second concern is that reliance on cross-state variation might admit the possibility of omitted variable bias if some other market-level factors not controlled for in the empirical

\footnotetext{
${ }^{28}$ Law and Kim (2005) find the same pattern using a hazard model.
} 
analyses are both correlated with the regulation and affect the outcomes. Because I am unable to completely rule out such a possibility, I include an extensive list of variables that might be correlated with the intensity of the occupational licensing regulation and affect the outcomes of interest, such as market-level population, per capita mean personal income, demographic characteristics (age, gender, and race composition), fraction of the population with at least a high school diploma, unemployment rate, geographic area, and SBSI index (which is designed to reflect major state-level costs imposed on businesses). To further mitigate this concern, I include year, or year interacted with division fixed effects.

A third concern is the focus only on states with stable licensing environments, which might possibly differ from states not included along a dimension other than, but correlated with, cosmetology licensing regulation. Descriptive statistics comparing states with low, medium, and high hours of regulation intensity with states that recently changed their regulation and were thus excluded are reported in Appendix D. There is no apparent pattern suggesting that states excluded would differ from those included in the analyses. Regression results reported in Appendix E show the excluded states not to be significantly different from the states included in the analyses along any of the considered dimensions including per capita number of cosmetology practitioners, prices of cosmetology services, personal income per capita, demographic composition, geographic area, or SBSI index. This increases my confidence that the set of excluded states is not significantly different from the states considered in my analyses. Including division fixed effects, as described above, further mitigates this concern.

\section{Conclusion}

This paper provides empirical evidence of the effects of occupational licensing on business activity, price of services, industry dynamics, selection, and providers of licensing training in the 
context of cosmetology. I find that states with more intense licensing requirements have neither fewer practitioners per capita nor higher prices for services. They do, however, have significantly lower entry and exit rates. The evidence is suggestive of fewer practitioners testing their fit for the occupation in states with more intense regulation, allowing even lower ability practitioners to survive in the market. I also find states with more stringent licensing requirements to have more occupational training instructors, a larger median size of training facilities, and larger school revenues and gross profits. Instructors, however, do not earn more in such states. These findings suggest that the benefits of occupational licensing accrue mostly to owners of training schools. 


\section{References}

Adams, A. Frank; John D. Jackson and Robert B. Ekelund. 2002. "Occupational Licensing in a "Competitive" Labor Market: The Case of Cosmetology." Journal of Labor Research, 23(2), pp. 261-78.

Akerlof, George A. 1970. "The Market for "Lemons": Quality Uncertainty and the Market Mechanism." Quarterly Journal of Economics, 84(3), pp. 488-500.

Angel, Juvenal L. 1970. Directory of Professional and Occupational Licensing in the United States. New York: World Trade Academy Press.

Angrist, Joshua D. and Jonathan Guryan. 2008. "Does Teacher Testing Raise Teacher Quality? Evidence from State Certification Requirements." Economics of Education Review, 27(5), pp. 483-503.

Arrow, Kenne th J. 1963. "Uncertainty and the Welfare Economics of Medical Care." American Economic Review, 53(5), pp. 941-73.

Asplund, Marcus and Volker Nocke. 2006. 'Firm Turnover in Imperfectly Competitive Markets." Review of Economic Studies, 73(2), pp. 295-327.

Backus, Matthew R. 2012. "General Comparative Statics for Industry Dynamics in Long-Run Equilibrium." Working Paper.

Bianco, David ed. Professional and Occupational Licensing Directory: A Descriptive Guide to State and Federal Licensing, Registration, and Certification Requirements. Detroit: Gale Research, 1993.

Bresnahan, Timothy F. and Peter C. Reiss. 1987. 'Do Entry Conditions Vary across Markets?" Brookings Papers on Economic Activity, 1, pp. 833-82.

. 1991. "Entry and Competition in Concentrated Markets." Journal of Political Economy, 99(5), pp. 977-1009.

Brinegar, Pam. 2006. "Professional and Occupational Regulation," In The Book of the States, ed. K. S. Chi, 457-64. Lexington, KY: Council of State Governments.

Campbell, Jeffrey R. and Hugo A. Hopenhayn. 2005. "Market Size Matters." Journal of Industrial Economics, 53(1), pp. 1-25.

Carpenter, Dick M.; Lisa Knepper; Angela C. Erickson and John K. Ross. 2012. "License to Work: A National Study of Burdens from Occupational Licensing," Arlington, VA: Institute for Justice.

Carroll, Sidney L. and Robert J. Gaston. 1981. "Occupational Restrictions and the Quality of Service Received: Some Evidence." Southern Economic Journal, 47(4), pp. 959-76. 
Council of State Governments. 1952. "Occupational Licensing Legislation in the States," Council of State Governments, Chicago, IL.

Davis, Steven J.; John Haltiwanger; C. J. Krizan; Javier Miranda; Alfred Nucci and Kristin Sandusky. 2007. "Measuring the Dynamics of Young and Small Businesses: Integrating the Employer and Nonemployer Universes," In NBER Working Paper Series. Cambridge: NBER.

Federman, Maya N.; David E. Harrington and Kathy J. Krynski. 2006. "The Impact of State Licensing Regulations on Low-Skilled Immigrants: The Case of Vietnamese Manucurists." American Economic Review, 96(2), pp. 237-41.

Friedman, Milton and Simon Kuzne ts. 1945. Income from Independent Professional Practice. New York: NBER.

Hopenhayn, Hugo A. 1992. "Exit, and Firm Dynamics in Long Run Equilibrium." Econometrica, 60(5), pp. 1127-50.

Hotz, V. Joseph and Mo Xiao. 2011. "The Impact of Regulations on the Supply and Quality of Care in Child Care Markets." American Economic Review, 101(5), pp. 1775-805.

Jarmin, Ron S. and Javier Miranda. 2002. "The Longitudinal Business Database." In Technical Report. U.S. Census Bureau.

Jovanovic, Boyan. 1982. "Selection and the Evolution of Industry." Econometrica, 50(3), pp. 649-70.

Keating, Raymond J. 2000. "Small Business Survival Index 2000," Small Business \& Entrepreneurship Council.

Klee, Mark A. 2010. "How Do Professional Licensing Regulations Affect Practitioners? New Evidence." Working Paper.

Kleine r, Morris M. 2006. Licensing Occupations: Ensuring Quality of Restricting Competition? Kalamazoo, MI: W.E. Upjohn Institute for Employment Research. . 2000. "Occupational Licensing." Journal of Economic Perspectives, 14(4), pp. 189-202.

Kleine r, Morris M. and Alan B. Krueger. 2013. "Analyzing the Extent and Influence of Occupational Licensing on the Labor Market." Journal of Labor Economics, 31(2), pp. 173-202.

Kleiner, Morris M. and Robert T. Kudrle. 2000. "Does Regulation Affect Economic Outcomes? The Case of Dentistry." Journal of Law and Economics, 43(2), pp. 547-82.

Kleiner, Morris M. and Kyoung Won Park. 2010. "Battles among Licensed Occupations: Analyzing Government Regulations on Labor Market Outcomes for Dentists and Hygienists." NBER Working Paper Series, (16560). 
Kugler, Adriana D. and Robert M. Sauer. 2005. "Doctors without Borders? Relicensing Requirements and Negative Selection in the Market for Physicians." Journal of Labor Economics, 23(3), pp. 437-65.

Larsen, Bradley. 2012. "Occupational Licensing and Quality: Distributional and Heterogeneous Effects in the Teaching Profession." Working Paper.

Law, Marc T. and Sukkoo Kim. 2005. "Specialization and Regulation: The Rise of Professionals and the Emergence of Occupational Licensing Regulation." Journal of Economic History, 65(3).

Leland, Hayne E. 1979. "Quacks, Lemons, and Licensing: A Theory of Minimum Quality Standards." Journal of Political Economy, 87(6), pp. 1328-46.

Paglie ro, Mario. 2011. "What Is the Objective of Professional Licensing? Evidence from the Us Market for Lawyers." International Journal of Industrial Organization, 29(4), pp. 473-83.

Pashigian, B. Peter. 1979. "Occupational Licensing and the Interstate Mobility of Professionals." Journal of Law and Economics, 22(1), pp. 1-25.

Peterson, Brenton; Sonal S. Pandya and David Leblang. 2013. "Doctors with Borders: Occupational Licensing as an Implicit Barrier to High Skill Migration." Working Paper.

Ruggles, Steven; J. Trent Alexander; Katie Genadek; Ronald Goeken; Matthew B. Schroeder and Matthew Sobek. 2010. "Integrated Public Use Microdata Series: Version 5.0," In. [Machine-readable database]. Minneapolis: University of Minnesota.

Scali-Sheahan, Maura T. 2008. "Barbers and Barbering: Quantifying the Profession to Analyze Present and Future Trends," Fort Lauderdale, FL: Nova Southeastern University (Ph.D. Dissertation).

Shapiro, Carl. 1986. "Investment, Moral Hazard, and Occupational Licensing." Review of Economic Studies, 53(5), pp. 843-62.

Smith, Adam. 1776. The Wealth of Nations. Reprint, New York, NY: Bantam Dell, 2003.

Stange, Kevin. 2012. "How Does Provider Supply and Regulation Influence Health Care Markets? Evidence from Nurse Practitioners and Physician Assistants." Working Paper.

Stigler, George J. 1971. "The Theory of Economic Regulation." Bell Journal of Economics and Management Science, 2(1), pp. 3-21.

Syverson, Chad. 2004. "Market Structure and Productivity: A Concrete Example." Journal of Political Economy, 112(6), pp. 1181-222.

Tenn, Steven. 2001. "Three Essays on the Relationship between Migration and Occupational Licensing," Chicago: The University of Chicago (Ph.D. Dissertation). 
Thornton, Robert J. and Edward J. Timmons. 2013. "Licensing One of the World's Oldest Professions: Massage." Journal of Law and Economics, 56(2), pp. 371-88.

Thornton, Robert J. and Andrew R. Weintraub. 1979. "Licensing in the Barbering Profession." Inudstrial and Labor Relations Review, 32(2), pp. 242-49.

Timmons, Edward J. and Robert J. Thornton. 2010. "The Licensing of Barbers in the USA." British Journal of Industrial Relations, 48(4), pp. 740-57.

Wheelan, Charles J. 1998. "An Empirical Examination of the Political Economy of Occupational Licensing," Chicago: The University of Chicago (Ph.D. Dissertation).

White, William D. 1980. "Mandatory Licensure of Registered Nurses: Introduction and Impact," In Occupational Licensure and Regulation, ed. S. Rottenberg. Washington and London: American Enterprise Institute for Policy Research. 


\section{Table 1 - Occupations in the Cosmetology Industry}

\begin{tabular}{lc}
\hline \hline Occupation & Cosmetology Industry (NAICS 812112) \\
\hline Hairdressers, Hairstylists, and Cosmetologists (\%) & 77.2 \\
Miscellaneous Personal Appearance Workers (\%) & 6.8 \\
Supervisors (\%) & 6.0 \\
Receptionists (\%) & 4.7 \\
Barbers (\%) & 0.7 \\
Other (\%) & 4.6 \\
\hline Number of Observations & 90,269 \\
\hline \hline
\end{tabular}

${ }^{29}$ The IPUMS ACS data are available courtesy of Ruggles et al. (2010). 
Table 2 - Descriptive Statistics for Practitione rs’ Regressions (ILBD \& LBD)

\begin{tabular}{|c|c|c|}
\hline \multirow[b]{2}{*}{ Variables } & \multicolumn{2}{|c|}{ Cosmetology } \\
\hline & Mean & SD \\
\hline Practitioners $/ 100,000$ people & 245.18 & 79.91 \\
\hline Nonemployer Practitioners/100,000 people & 177.72 & 69.54 \\
\hline Median Annual Revenues (2010 \$) & 15,993 & 4,981 \\
\hline Entry Rate (\%) & 24.87 & 15.99 \\
\hline Exit Rate (\%) & 22.55 & 10.13 \\
\hline Nonemployer Entry Rate (\%) & 26.59 & 17.23 \\
\hline Nonemployer Exit Rate (\%) & 23.67 & 10.86 \\
\hline Gap in Nonemployer Entrants’ Revenues* (2010 \$) & 4,334 & 8,283 \\
\hline Hours Requirement (in 100s) & 15.92 & 2.71 \\
\hline Population & 100,087 & 337,417 \\
\hline Population: Mean Personal Income (2010 \$) & 30,278 & 7,476 \\
\hline Population: Males (\%) & 49.57 & 1.88 \\
\hline Population: Caucasians (\%) & 88.01 & 15.16 \\
\hline Population: African Americans (\%) & 8.67 & 13.89 \\
\hline Population: Other Race (\%) & 3.32 & 6.86 \\
\hline Population: Age 14 and Younger (\%) & 20.35 & 2.80 \\
\hline Population: Age 15-64 (\%) & 64.28 & 3.51 \\
\hline Population: Age 65 and Older (\%) & 15.37 & 4.10 \\
\hline Population: At Least High School Diploma (\%) & 83.36 & 7.22 \\
\hline Population: Unemployed (\%) & 5.64 & 2.60 \\
\hline Geographic Area (Square Miles) & 832 & 913 \\
\hline Indicator for MSA Central County & 0.1698 & 0.3755 \\
\hline SBSI & 40.22 & 6.96 \\
\hline Number of States & \multicolumn{2}{|c|}{32} \\
\hline Number of Counties & \multicolumn{2}{|c|}{2,055} \\
\hline Number of Observations & \multicolumn{2}{|c|}{30,825} \\
\hline Period & \multicolumn{2}{|c|}{ 1995-2009 } \\
\hline
\end{tabular}

Notes: The observations are at the county-year level (2,055 counties times 15 years). * Gap in Nonemployer Entrants' Revenues is defined as median annual revenues of an incumbent minus median annual revenues of an entrant. Hours Requirement varies only across states. At Least High School Diploma and Geographic Area variables vary only across counties. The SBSI index, which varies only across states, is designed to take into account major state-level costs imposed on businesses; the greater the value, the greater the costs. In the sample, the index rang es from 24.9 (South Dakota) to 68.2 (D.C.). 
Table 3 - Descriptive Statistics for Usual Hours of Work (ACS)

\begin{tabular}{|c|c|c|}
\hline Variables & Mean & SD \\
\hline Weekly Hours Worked & 33.61 & 11.78 \\
\hline Employee: Age & 41.30 & 13.75 \\
\hline Employee: Age Squared & 1894.40 & 1209.94 \\
\hline Employee: Male (\%) & 8.26 & 27.53 \\
\hline Employee: Caucasian (\%) & 80.38 & 39.71 \\
\hline Employee: African American (\%) & 8.50 & 27.89 \\
\hline Employee: Asian Race (\%) & 4.80 & 21.38 \\
\hline Employee: Other Race (\%) & 6.31 & 24.32 \\
\hline Employee: Hispanic (\%) & 12.16 & 32.68 \\
\hline Employee: Less than 12 Grades (\%) & 6.06 & 23.85 \\
\hline Employee: High School(\%) & 59.82 & 59.82 \\
\hline Employee: Some College (\%) & 29.03 & 45.39 \\
\hline Employee: College (\%) & 5.09 & 21.99 \\
\hline Employee: Single (\%) & 22.53 & 41.78 \\
\hline Employee: Married (\%) & 56.19 & 49.62 \\
\hline Employee: Not Single or Married (\%) & 21.28 & 40.93 \\
\hline Employee: At Least One Child (\%) & 46.49 & 49.88 \\
\hline Employee: Naturalized Citizen (\%) & 10.14 & 30.19 \\
\hline Employee: Not a Citizen (\%) & 6.10 & 23.93 \\
\hline Hours Requirement (in 100s) & 14.53 & 2.55 \\
\hline Population & $14,675,684$ & $11,058,579$ \\
\hline Population: Mean Personal Income (2010 \$) & 39,929 & 5,556 \\
\hline Population: Males (\%) & 49.06 & 0.53 \\
\hline Population: Caucasians (\%) & 79.41 & 7.62 \\
\hline Population: African Americans (\%) & 13.19 & 7.62 \\
\hline Population: Other Race (\%) & 7.40 & 4.93 \\
\hline Population: 14 and Younger (\%) & 20.31 & 1.70 \\
\hline Population: Age 15-64 (\%) & 66.88 & 1.06 \\
\hline Population: 65 and Older (\%) & 12.81 & 1.94 \\
\hline Population: At Least High School Diploma (\%) & 79.70 & 3.58 \\
\hline Population: Unemployed (\%) & 6.21 & 2.28 \\
\hline Geographic Area (Square Miles) & 162,861 & 144,135 \\
\hline SBSI & 41.31 & 7.26 \\
\hline Number of States & \multicolumn{2}{|r|}{32} \\
\hline Number of Observations & \multicolumn{2}{|r|}{46,425} \\
\hline Period & \multicolumn{2}{|r|}{$1999-2010$} \\
\hline
\end{tabular}

Notes: The observations are at the state-year level. The sample contains only cosmetologists, based on the Standard Occupational Classification (SOC), at least eighteen years old, with usual weekly hours of w ork greater than zero and not exceeding eighty, and personal income between $\$ 1,000$ and \$150,000 (2010 \$). Hours Requirement, At Least High School Diploma, Geographic Area, and the SBSI variables vary only across states. 
Table 4 - Descriptive Statistics for Prices of Cosmetology Services (COLI)

\begin{tabular}{lcc}
\hline & \multicolumn{2}{c}{ Cosmetology } \\
\hline \multicolumn{1}{c}{ Variables } & Mean & SD \\
\hline Price (2010 \$) & 30.42 & 5.51 \\
\hline Hours Requirement (in 100s) & 15.74 & 2.92 \\
Population & $6,705,233$ & $7,532,375$ \\
Population: Mean Personal Income (2010 \$) & 36,702 & 7,044 \\
Population: Males (\%) & 48.94 & 0.66 \\
Population: Caucasians (\%) & 81.21 & 12.69 \\
Population: African Americans (\%) & 13.83 & 12.88 \\
Population: Other Race (\%) & 4.96 & 3.49 \\
Population: Age 14 and Younger (\%) & 20.62 & 1.92 \\
Population: Age 15-64 (\%) & 66.37 & 1.56 \\
Population: Age 65 and Older (\%) & 13.02 & 1.70 \\
Population: At Least High School Diploma (\%) & 80.72 & 4.43 \\
Population: Unemployed (\%) & 5.08 & 1.60 \\
Geographic Area (Square Miles) & 114,619 & 103,931 \\
SBSI & 42.21 & 8.21 \\
\hline \multicolumn{2}{c}{ Number of States } & \multicolumn{2}{c}{32} \\
\multicolumn{2}{c}{ Number of Observations } & $1995-2009$ \\
\hline \hline
\end{tabular}

Notes: Price refers to the price for women's cut and shampoo blow-dry. Observations are at the state-year level. As price data are missing for some state-years, the number of observations is smaller than 480 (32 states times 15 years). Hours Requirement, At Least High School Diploma, Geographic Area, and the SBSI variables vary only across states. 
Table 5 - Descriptive Statistics for Analyses of Providers of Occupational Training (LBD)

\begin{tabular}{lcc}
\hline \multicolumn{3}{c}{ Providers of Occupational Training } \\
\hline \multicolumn{1}{c}{ Variables } & Mean & SD \\
\hline Instructors/100,000 people & 4.79 & 2.63 \\
Instructors' Median Wage (2010 \$) & 23,774 & 4,715 \\
Number of School Establishments & 32.61 & 31.97 \\
School Establishment Size (Instructors) & 8.91 & 3.11 \\
\hline Hours Requirement (in 100s) & 15.67 & 2.86 \\
Population & $6,464,328$ & $7,416,688$ \\
Population: Mean Personal Income (2010 \$) & 36,754 & 6,949 \\
Population: Males (\%) & 48.92 & 0.65 \\
Population: Caucasians (\%) & 81.83 & 12.69 \\
Population: African Americans (\%) & 13.31 & 12.76 \\
Population: Other Race (\%) & 4.86 & 3.43 \\
Population: Age 14 and Younger (\%) & 20.56 & 1.89 \\
Population: Age 15-64 (\%) & 66.37 & 1.54 \\
Population: Age 65 and Older (\%) & 13.06 & 1.68 \\
Population: At Least High School Diploma (\%) & 80.86 & 4.42 \\
Population: Unemployed (\%) & 5.05 & 1.57 \\
Geographic Area (Square Miles) & 110,128 & 102,983 \\
SBSI & 42.55 & 8.31 \\
\hline \multicolumn{2}{c}{ Number of States } & \multicolumn{2}{c}{32} \\
\hline \hline
\end{tabular}

Notes: The observations are at the state-year level (32 states times 15 years). Hours Requir em ent, At Least High School Diploma, Geographic Area, and the SBSI variables vary only across states. The At Least High School Diploma variable is from the Decennial Census of 2000. 
Table 6 - OLS Regression Results: Number of Practitioners per Capita

\begin{tabular}{lcccc}
\hline \hline & \multicolumn{2}{c}{ Log(Practitioners/Capita) } & \multicolumn{2}{c}{ Log(Nonemp. Pract./Capita) } \\
\hline Hours Requirement (in 100s) & $\mathbf{0 . 0 0 2}$ & $\mathbf{- 0 . 0 0 3}$ & $\mathbf{0 . 0 1 3}$ & $\mathbf{- 0 . 0 0 6}$ \\
& $(0.006)$ & $(0.005)$ & $(0.011)$ & $(0.010)$ \\
\hline Control Variables & Yes & Yes & Yes & Yes \\
\hline Fixed Effects - Year & Yes & No & Yes & No \\
Fixed Effects - Year $\times$ Division & No & Yes & No & Yes \\
\hline Number of Observations & 30,825 & 30,825 & 30,825 & 30,825 \\
Period & $1995-2009$ & $1995-2009$ & $1995-2009$ & $1995-2009$ \\
\hline \hline
\end{tabular}

Notes: Standard errors are clustered by state. ***, **, and * indicate statistical signific ance at the $1 \%, 5 \%$, and $10 \%$ level. Observations are at the county-year level. All regressions include the following set of control variables: log of per capita mean personal income, log of geographic area, fraction of males, fraction of African Americans, fraction of population other than African American or Caucasian, fraction of population age 14 and younger, fraction of population age 65 and older, fraction of population with at least a high school diploma, unemployment rate, SBSI index, and an indicator for central counties of the Metropolitan Statistical Area. 
Table 7 - OLS Regression Results: Weekly Hours Worked

\begin{tabular}{lcc}
\hline \hline & \multicolumn{2}{c}{ Log(Weekly Hours Worked) } \\
\hline Hours Requirement (in 100s) & $\mathbf{0 . 0 0 7}$ & $\mathbf{0 . 0 0 1}$ \\
& $(0.005)$ & $(0.034)$ \\
\hline Control Variables & Yes & Yes \\
\hline Fixed Effects - Year & Yes & No \\
Fixed Effects - Year $\times$ Division & No & Yes \\
\hline Number of Observations & 46,425 & 46,425 \\
Period & $1999-2010$ & $1999-2010$ \\
\hline \hline
\end{tabular}

Notes: Standard errors are clustered by state. ${ }^{* * *},{ }^{* *}$, and $*$ indicate statistical significance at the $1 \%$, 5\%, and 10\% level. All regressions contain employee-level variables shown in Table 3 that control for age, gender, race, ethnicity, education, marital status, presence of children, and citizenship. The regressions also include the following state-level controls: log of population, log of per capita mean personal income, log of geographic area, fraction of males, fraction of Afric an Americans, fraction of population other than African American or Caucasian, fraction of population age 14 and younger, fraction of population age 65 and older, fraction of population with at least a high school diploma, unemployment rate, and SBSI index. 
Table 8 - OLS Regression Results: Prices of Cosmetology Services

\begin{tabular}{lcc}
\hline \hline & \multicolumn{2}{c}{$\log ($ Price) } \\
\hline Hours Requirement (in 100s) & $\mathbf{- 0 . 0 0 5}$ & $\mathbf{0 . 0 0 0 5}$ \\
& $(0.006)$ & $(0.0078)$ \\
\hline Control Variables & Yes & Yes \\
\hline Fixed Effects - Year & Yes & No \\
Fixed Effects - Year $\times$ Division & No & Yes \\
\hline Number of Observations & 454 & 454 \\
Period & $1995-2009$ & $1995-2009$ \\
\hline \hline
\end{tabular}

Notes: Standard errors are clustered by state. ${ }^{* * *},{ }^{* *}$, and $*$ indicate statistical signific ance at the $1 \%, 5 \%$, and $10 \%$ level. Price is the price for women's cut and shampoo blow-dry and is from the Cost of Living Index (COLI) data published by the Council for Community and Economic Research (C2ER). Observations are at the state-year level. As price data are missing for some state-years, the number of observations is smaller than 480 (32 states times 15 years). All regressions include the following set of control variables: log of population, log of per capita mean personal inc ome, log of geographic area, fraction of males, fraction of African Americans, fraction of population other than African American or Caucasian, fraction of population age 14 and younger, fraction of population age 65 and older, fraction of population with at least a high school diploma, unemployment rate, and SBSI index. 
Table 9 - OLS Regression Results: Median Annual Revenues

\begin{tabular}{lcc}
\hline \hline & \multicolumn{2}{l}{ Log(Median Annual Revenues) } \\
\hline Hours Requirement (in 100s) & $\mathbf{0 . 0 0 9 *}$ & $\mathbf{- 0 . 0 1 0 *}$ \\
& $(0.005)$ & $(0.005)$ \\
\hline Control Variables & Yes & Yes \\
\hline Fixed Effects - Year & Yes & No \\
Fixed Effects - Year $\times$ Division & No & 30,825 \\
\hline Number of Observations & 30,825 & $1995-2009$ \\
Period & $1995-2009$ & \\
\hline \hline
\end{tabular}

Notes: Standard errors are clustered by state. ${ }^{* * *},{ }^{* *}$, and $*$ indicate statistical significance at the $1 \%, 5 \%$, and $10 \%$ level. Observations are at the county-year level. The dependent variable is a logarithm of median annual revenues of nonemployer practitioners in a market in a given year. All regressions include the following set of control variables: log of per capita mean personal income, log of geographic area, fraction of males, fraction of African Americans, fraction of population other than Afric an American or Caucasian, fraction of population age 14 and younger, fraction of population age 65 and older, fraction of population with at least a high school diploma, unemployment rate, SBSI index, and an indicator for central counties of the Metropolitan Statistical Area. 
Table 10 - OLS Regression Results: Entry and Exit Rates

\begin{tabular}{lcccc}
\hline \hline & \multicolumn{2}{c}{ Entry Rate (\%) } & \multicolumn{2}{c}{ Nonemployers' Entry Rate (\%) } \\
\hline Hours Requirement (in 100s) & $\mathbf{- 0 . 1 4 1}$ & $\mathbf{- 0 . 5 0 0 * *}$ & $\mathbf{- 0 . 1 5 4}$ & $\mathbf{- 0 . 6 3 6 * *}$ \\
& $(0.159)$ & $(0.122)$ & $(0.218)$ & $(0.193)$ \\
\hline Control Variables & Yes & Yes & Yes & Yes \\
\hline Fixed Effects - Year & Yes & No & Yes & No \\
Fixed Effects - Year $\times$ Division & No & Yes & No & Yes \\
\hline Number of Observations & 30,825 & 30,825 & 30,825 & 30,825 \\
Period & $1995-2009$ & $1995-2009$ & $1995-2009$ & $1995-2009$ \\
\hline \hline & \multicolumn{2}{c}{ Exit Rate (\%) } & Nonemployers' Exit Rate (\%) \\
\hline Hours Requirement (in 100s) & $\mathbf{- 0 . 1 2 9}$ & $\mathbf{- 0 . 4 0 8 * * *}$ & $\mathbf{- 0 . 2 5 9}$ & $\mathbf{- 0 . 5 2 2 * * *}$ \\
& $(0.123)$ & $(0.084)$ & $(0.176)$ & $(0.133)$ \\
\hline Control Variables & Yes & Yes & Yes & Yes \\
\hline Fixed Effects - Year & Yes & No & Yes & No \\
Fixed Effects - Year $\times$ Division & No & Yes & No & Yes \\
\hline Number of Observations & 30,825 & 30,825 & 30,825 & 30,825 \\
Period & $1995-2009$ & $1995-2009$ & $1995-2009$ & $1995-2009$ \\
\hline \hline
\end{tabular}

Notes: Standard errors are clustered by state. ${ }^{* * *},{ }^{* *}$, and $*$ indicate statistical signific anc e at the $1 \%, 5 \%$, and $10 \%$ level. Observations are at the county-year level. All regressions also inc lude the log of lagged population, log of lagged per capita mean personal income, log of geographic area, lagged fraction of males, lagged fraction of African Americans, lagged fraction of population other than African American or Caucasian, lagged fraction of population age 14 and younger, lagged fraction of population age 65 and older, fraction of population with at a least high school diploma, unemployment rate, SBSI index, and an indicator for central counties of the Metropolitan Statistical Area. 
Table 11 - OLS Regression Results: Gap in Entrants' Revenues $\dagger$

\begin{tabular}{lcc}
\hline \hline & \multicolumn{2}{c}{ Gap in Entrants' Revenues } \\
\hline Hours Requirement (in 100s) & $\mathbf{2 3 . 9}$ & $\mathbf{- 1 8 1 . 9 * * *}$ \\
& $(62.9)$ & $(44.0)$ \\
\hline Control Variables & Yes & Yes \\
\hline Fixed Effects - Year & No & No \\
Fixed Effects - Year $\times$ Division & No & Yes \\
\hline Number of Observations & 30,825 & 30,825 \\
Period & $1995-2009$ & $1995-2009$ \\
\hline \hline
\end{tabular}

Notes: † Gap in Entrants' Revenues is defined as median annual revenues of a nonemployer incumbent minus median annual revenues of a nonemployer entrant. Standard errors are clustered by state. ${ }^{* * *},{ }^{* *}$, and $*$ indicate statistical signific ance at the $1 \%, 5 \%$, and $10 \%$ level. Observations are at the county-year level. All regressions include the following set of control variables: log of population, log of per capita mean personal income, log of geographic area, fraction of males, fraction of African Americans, fraction of population other than African American or Caucasian, fraction of population age 14 and younger, fraction of population age 65 and older, fraction of population with at least a high school diploma, unemployment rate, SBSI index, and an indicator for central counties of the Metropolitan Statistical Area. 
Table 12 - OLS Regression Results: Instructors

\begin{tabular}{lcccc}
\hline \hline & \multicolumn{2}{c}{ Log(Instructors/Capita) } & \multicolumn{2}{c}{ Log(Instructors' Median Wage) } \\
\hline Hours Requirement (in 100s) & $\mathbf{0 . 0 6 4 * * *}$ & $\mathbf{0 . 0 5 1 * * *}$ & $\mathbf{0 . 0 0 0 9}$ & $\mathbf{- 0 . 0 0 4}$ \\
& $(0.012)$ & $(0.017)$ & $(0.0068)$ & $(0.006)$ \\
\hline Control Variables & Yes & Yes & Yes & Yes \\
\hline Fixed Effects - Year & Yes & Yes & Yes & Yes \\
Fixed Effects - Division & No & Yes & No & Yes \\
\hline Number of Observations & 480 & 480 & 480 & 480 \\
Period & $1995-2009$ & $1995-2009$ & $1995-2009$ & $1995-2009$ \\
\hline \hline
\end{tabular}

Notes: Standard errors are clustered by state. ***, **, and * indicate statistical signific ance at the $1 \%, 5 \%$, and $10 \%$ level. Observations are at the state-year level. All regressions include year fixed effects and the following set of control variables: log of per capita mean personal income, log of geographic area, fraction of males, fraction of African Americans, fraction of population other than African American or Caucasian, fraction of population age 14 and younger, fraction of population age 65 and older, fraction of population with at least a high school diploma, unemployment rate, and SBSI index. Instructors' Median Wage regressions also include log of population. 
Table 13 - OLS Regression Results: Schools

\begin{tabular}{lcccc}
\hline \hline & \multicolumn{2}{c}{$\begin{array}{c}\text { Log(Number of School } \\
\text { Establishments) }\end{array}$} & \multicolumn{2}{c}{ Log(School Establishment Size) } \\
\hline Hours Requirement (in 100s) & $\mathbf{0 . 0 0 6}$ & $\mathbf{- 0 . 0 1 4}$ & $\mathbf{0 . 0 4 9} * * *$ & $\mathbf{0 . 0 6 3} * * *$ \\
& $(0.022)$ & $(0.019)$ & $(0.015)$ & $(0.021)$ \\
\hline Control Variables & Yes & Yes & Yes & Yes \\
\hline Fixed Effects - Year & Yes & Yes & Yes & Yes \\
Fixed Effects - Division & No & Yes & No & Yes \\
\hline Number of Observations & 480 & 480 & 480 & 480 \\
Period & $1995-2009$ & $1995-2009$ & $1995-2009$ & $1995-2009$ \\
\hline \hline
\end{tabular}

Notes: Standard errors are clustered by state. ***, **, and * indicate statistic al signific ance at the $1 \%, 5 \%$, and $10 \%$ level. Observations are at the state-year level. All regressions include year fixed effects and the following set of control variables: log of population, log of per capita mean personal income, log of geographic area, fraction of males, fraction of African Americans, fraction of population other than African American or Caucasian, fraction of population age 14 and younger, fraction of population age 65 and older, fraction of population with at a least high school diploma, unemployment rate, and SBSI index. School Establishment Size is defined as the stateyear median size of a school establishment in terms of number of instructors. 
Table 14 - OLS Regression Results: School Revenues and Margins

\begin{tabular}{lcccc}
\hline \hline & $\begin{array}{c}\text { Log(Avg. Revenues of } \\
\text { School Establishments) }\end{array}$ & $\begin{array}{c}\text { Log(Avg. Gross Margin of } \\
\text { School Est.) }\end{array}$ \\
\hline Hours Requirement (in 100s) & $\mathbf{0 . 0 9 2 * * *}$ & $\mathbf{0 . 2 0 7 * * *}$ & $\mathbf{0 . 1 0 1 * * *}$ & $\mathbf{0 . 2 0 3 * * *}$ \\
& $(0.032)$ & $(0.064)$ & $(0.028)$ & $(0.066)$ \\
\hline Fixed Effects - Division & No & Yes & No & Yes \\
\hline Number of Observations & 25 & 25 & 25 & 25 \\
\hline \hline
\end{tabular}


Table 15 - OLS Regression Results: Explaining the Intensity of Occupational Licensing Regulation

\begin{tabular}{lcccc}
\hline & \multicolumn{4}{c}{ Hours Requirement for Cosmetologists } \\
\hline \multicolumn{1}{c}{ Specification A } & $\mathbf{( 1 )}$ & $\mathbf{( 2 )}$ & $\mathbf{( 3 )}$ & $\mathbf{( 4 )}$ \\
\hline Log(Practitioners per Capita) & $\mathbf{3 2 4 . 1 1 ^ { * * * }}$ & $\mathbf{4 2 3 . 4 5 * * *}$ & $\mathbf{2 9 6 . 9 4}$ & $\mathbf{4 8 0 . 3 8 * *}$ \\
& $(114.26)$ & $(136.97)$ & $(263.07)$ & $(189.92)$ \\
Urbanization (\%) & $\mathbf{- 1 0 . 7 6 * * *}$ & $\mathbf{- 1 0 . 8 9 * * *}$ & $\mathbf{- 8 . 4 2 * *}$ & $\mathbf{- 1 0 . 9 7 * *}$ \\
& $(3.28)$ & $(2.92)$ & $(3.16)$ & $(2.66)$ \\
\hline Fixed Effects - Division & No & No & No & No \\
\hline Number of Observations & 32 & 32 & 32 & 32 \\
Census Data from Year & 1900 & 1910 & 1920 & 1930 \\
\hline \multicolumn{1}{c}{ Specification B } & $\mathbf{( 1 )}$ & $\mathbf{( 2 )}$ & $\mathbf{( 3 )}$ & $\mathbf{( 4 )}$ \\
\hline Log(Practitioners per Capita) & $\mathbf{1 2 2 . 2 7}$ & $\mathbf{1 4 0 . 7 8}$ & $\mathbf{- 1 4 9 . 9 8}$ & $\mathbf{- 1 2 . 3 2}$ \\
& $(129.23)$ & $(178.03)$ & $(298.13)$ & $(231.34)$ \\
Urbanization (\%) & $\mathbf{- 3 . 9 3}$ & $\mathbf{- 4 . 1 7}$ & $\mathbf{- 0 . 5 5}$ & $\mathbf{- 2 . 7 8}$ \\
& $(3.95)$ & $(4.13)$ & $(4.29)$ & $(3.64)$ \\
\hline Fixed Effects - Division & Yes & Yes & Yes & Yes \\
\hline Number of Observations & 32 & 32 & 32 & 32 \\
Census Data from Year & 1900 & 1910 & 1920 & 1930 \\
\hline \hline
\end{tabular}

Notes: Robust standard errors are in parentheses. ${ }^{* * *}, * *$, and $*$ indicate statistical signific ance at the $1 \%, 5 \%$, and $10 \%$ level. The observations are states with stable licensing requirements per Section 4.1. Because the Census did not separate the two in the relevant periods, I include as practitioners both barbers and hairdressers. 
Figure 1 - Cosmetology Training Hours Requirements (2010)

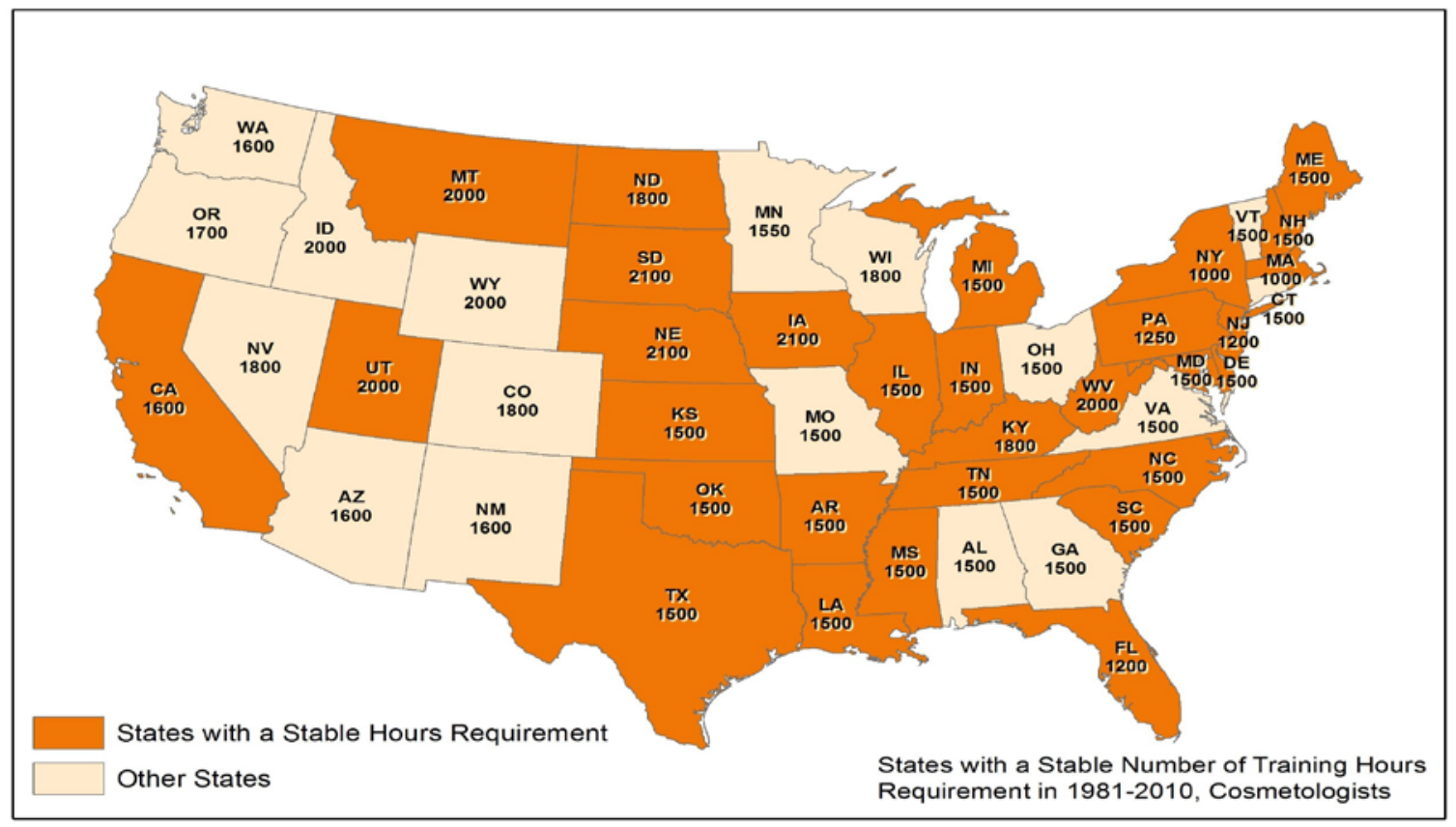

Figure 2 - Robustness Checks: Extended Set of States (2010)

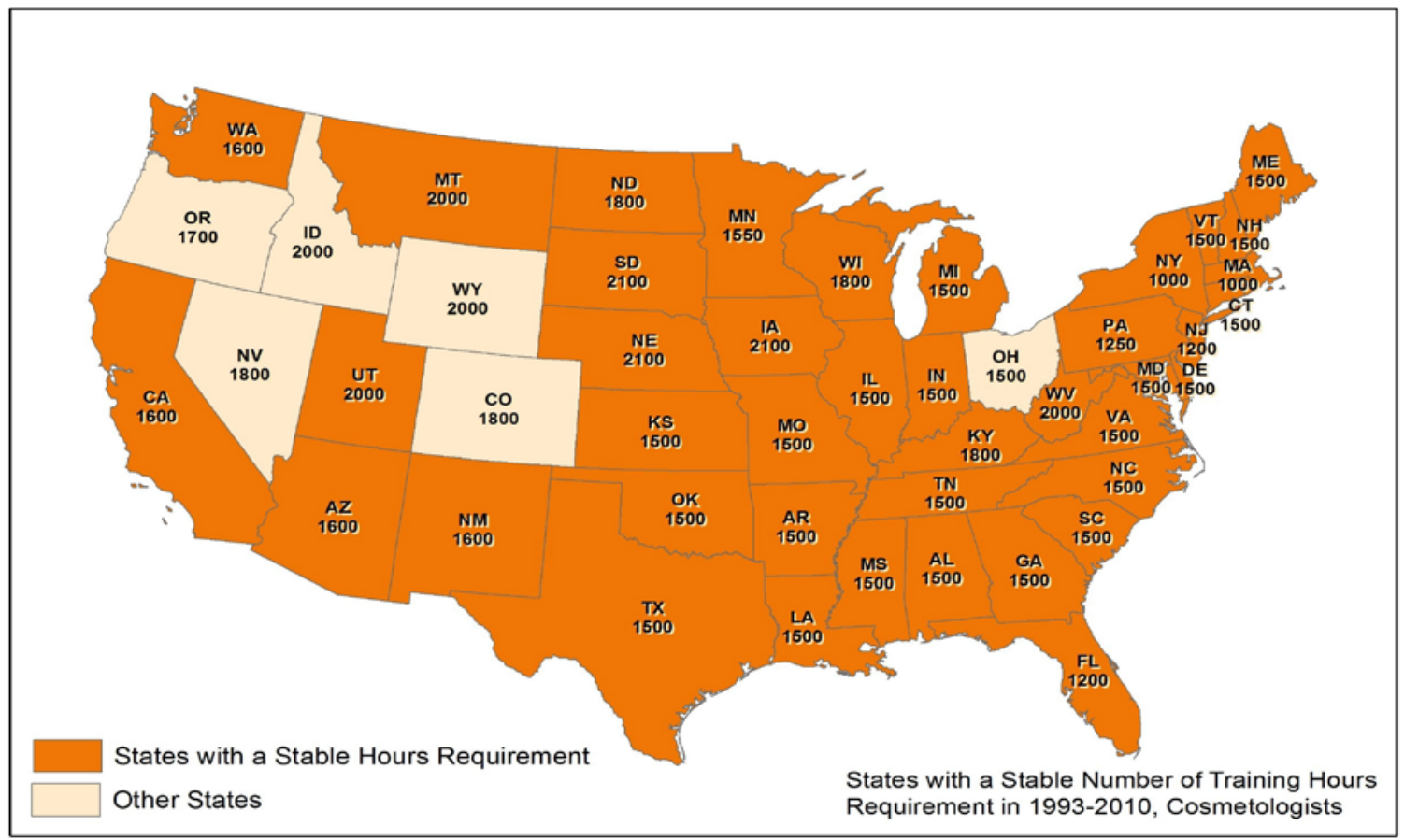

Notes: As robustness checks, I use an extended set of 44 states (including Alaska with 1,650 hours, not depicted) that did not have a change in hours regulation in the 1993-2010 period and do not have multiple licensing categories (except for Georgia, in which cosmetology and hair stylist categories differ by only 175 hours). 
Appendix A - Cosmetology Training Hours Requirements in 2010

\begin{tabular}{|c|c|c|c|}
\hline State & Cosmetology Hours & State & Cosmetology Hours \\
\hline Alabama $^{2}$ & 1,500 & Montana $^{1,2}$ & 2,000 \\
\hline Alaska $^{2}$ & 1,650 & Nebraska $a^{1,2}$ & 2,100 \\
\hline Arizona $^{2}$ & 1,600 & Nevada & $1,800^{*}$ \\
\hline Arkansas ${ }^{1,2}$ & 1,500 & New Hampshire ${ }^{1,2}$ & 1,500 \\
\hline California $^{1,2}$ & 1,600 & New Jersey ${ }^{1,2}$ & 1,200 \\
\hline Colorado & $1,800^{*}$ & New Mexico $^{2}$ & 1,600 \\
\hline Connecticut $^{2}$ & 1,500 & New York ${ }^{1,2}$ & 1,000 \\
\hline Delaware $^{1,2}$ & 1,500 & North Carolina $^{1,2}$ & 1,500 \\
\hline D.C. ${ }^{1,2}$ & 1,500 & North Dakota $^{1,2}$ & 1,800 \\
\hline Florida $^{1,2}$ & 1,200 & Ohio & $1,500 *$ \\
\hline Georgia $^{2}$ & $1,500^{*}$ & Oklahoma $^{1,2}$ & 1,500 \\
\hline Haw aii & $1,800 *$ & Oregon & 1,700 \\
\hline Idaho & $2,000^{*}$ & Pennsylvania $^{1,2}$ & 1,250 \\
\hline Illinois $^{1,2}$ & 1,500 & Rhode Island $^{1,2}$ & 1,500 \\
\hline Indiana $^{1,2}$ & 1,500 & South Carolina $^{1,2}$ & 1,500 \\
\hline Iowa $^{1,2}$ & 2,100 & South Dakota ${ }^{1,2}$ & 2,100 \\
\hline Kansas $^{1,2}$ & 1,500 & Tennessee $^{1,2}$ & 1,500 \\
\hline Kentucky ${ }^{1,2}$ & 1,800 & Texas $^{1,2}$ & 1,500 \\
\hline Louisiana $^{1,2}$ & 1,500 & Utah $^{1,2}$ & 2,000 \\
\hline Maine $^{1,2}$ & 1,500 & Vermont $^{2}$ & 1,500 \\
\hline Maryland $^{1,2}$ & 1,500 & Virginia $^{2}$ & 1,500 \\
\hline Massachusetts $^{1,2}$ & 1,000 & Washington $^{2}$ & 1,600 \\
\hline Michigan $^{1,2}$ & 1,500 & West Virginiaa,2 $^{1,2}$ & 2,000 \\
\hline Minnesota $^{2}$ & 1,550 & Wisconsin $^{2}$ & 1,800 \\
\hline Mississippi $^{1,2}$ & 1,500 & Wyoming & $2,000^{*}$ \\
\hline Missouri $^{2}$ & 1,500 & Mean & 1,599 \\
\hline
\end{tabular}

1 Indicates the 32 states in the contiguous United States with no documented change in the cosmetology training hours requirement from 1981 to 2010 and no multiple cosmetology categories. The states are depicted in Figure 1.

${ }^{2}$ Indicates the 44 states with no documented change in the cosmetology training hours requirement from 1993 to 2010 and no multiple cosmetology categories. The states are depicted in Figure 2.

* Indicates cases with an alternative category of cosmetology professional that has a somewhat different title and different training hours requirement (for instance, Cosmetologists and Hair Designers in Ohio, with requirements of 1,500 and 1,200 hours, respectively).

Source: Cosmetology requirements are based on 2010 Endorsement Report of the NationalInterstate Council of State Boards of Cosmetology and my own compilations. Thanks to Morris Kleiner, I also have cosmetology regulation data for several years since 1981. Additionally, I us ed cosmetology regulations in Bianco (1993). 
Appendix B - List of Dependent Variables and Sources

\begin{tabular}{lcc}
\hline \hline \multicolumn{1}{c}{ Dependent Variable } & Variation & Data Source \\
\hline Practitioners per Capita & Practitioners & \\
Nonemployer Practitioners per Capita & County-Year & ILBD \& LBD, Census \\
Weekly Hours Worked & County-Year & ILBD, Census \\
Price & Individual & ACS \\
Median Annual Revenues & State-Year & COLI \\
Entry Rate & County-Year & ILBD \\
Exit Rate & County-Year & ILBD \& LBD \\
Nonemployer Entry Rate & County-Year & ILBD \& LBD \\
Nonemployer Exit Rate & County-Year & ILBD \\
Gap in Entrants' Revenues & County-Year & ILBD \\
\hline & County-Year & ILBD \\
\hline Instructors per Capita & Providers of Occupational Training & \\
Instructors' Median Wage & State-Year & LBD, Census \\
Number of School Establishments & State-Year & LBD \\
School Establishment Size & State-Year & LBD \\
Avg. Revenues per School Establishment & State-Year & LBD \\
Avg. Gross Margin per School Establishment & State & EC 2002 \\
\hline \hline
\end{tabular}

Notes: ILBD stands for Integrated Longitudinal Business Database (a confidential data set from the U.S. Census Bureau), LBD for Longitudinal Business Database (a confidential data set from the U.S. Census Bureau), Census for population data (a publicly available data set from the U.S. Census Bureau), ACS for the Americ an Community Survey (a publicly available data set from the U.S. Census Bureau), COLI for the Cost of Living Index (a proprietary data set from the Council for Community and Economic Research), and EC 2002 for the Economic Census of 2002 (a publicly available version of the data from the U.S. Census Bureau). 


\section{Appendix C - OLS Regression Results: Explaining the Year of Adoption of Occupational Licensing Regulation}

\begin{tabular}{lcccc}
\hline \hline \multicolumn{1}{c}{ Specification A } & \multicolumn{4}{c}{ Cosmetology: Year of Adoption } \\
\hline Log(Practitioners per Capita) & $\mathbf{( 1 )}$ & $\mathbf{( 2 )}$ & $\mathbf{( 3 )}$ & $\mathbf{( 4 )}$ \\
\hline Urbanization (\%) & $\mathbf{- 7 . 7 2 * *}$ & $\mathbf{- 9 . 4 0 * *}$ & $\mathbf{- 7 . 9 6}$ & $\mathbf{- 1 0 . 6 0 * *}$ \\
& $(3.17)$ & $(3.92)$ & $(5.02)$ & $(4.85)$ \\
& $\mathbf{0 . 1 2}$ & $\mathbf{0 . 1 0}$ & $\mathbf{0 . 0 4}$ & $\mathbf{0 . 0 7}$ \\
\hline Fixed Effects - Division & $(0.08)$ & $(0.06)$ & $(0.06)$ & $(0.06)$ \\
\hline Number of Observations & No & No & No & No \\
Census Data from Year & 30 & 30 & 30 & 30 \\
\hline \hline & 1900 & 1910 & 1920 & 1930 \\
\hline Specification B & $\mathbf{( 1 )}$ & $\mathbf{( 2 )}$ & $\mathbf{( 3 )}$ & $\mathbf{( 4 )}$ \\
\hline Urbanization (\%) & $\mathbf{- 0 . 1 5}$ & $\mathbf{1 . 8 9}$ & $\mathbf{4 . 6 8}$ & $\mathbf{5 . 8 7}$ \\
& $\mathbf{( 4 . 0 0 )}$ & $(6.09)$ & $(6.04)$ & $\mathbf{( 8 . 7 1 )}$ \\
\hline Fixed Effects - Division & $\mathbf{- 0 . 1 0}$ & $\mathbf{- 0 . 1 3}$ & $\mathbf{- 0 . 1 4}$ & $\mathbf{- 0 . 1 6}$ \\
\hline Number of Observations & $(0.09)$ & $(0.10)$ & $(0.09)$ & $(0.10)$ \\
Census Data from Year & Yes & Yes & Yes & Yes \\
\hline \hline
\end{tabular}

Notes: Robust standard errors are in parentheses. ${ }^{* * *}, * *$, and $*$ indicate statistical signific ance at the $1 \%, 5 \%$, and $10 \%$ level. The observations are states with stable licensing requirements per Section 4.1 and known year of adoption of occupational licensing. Because the Census did not separate the two in the relevant periods, I include as practitioners both barbers and hairdressers. 


\section{Appendix D - Descriptive Statistics of States}

\begin{tabular}{lcccc}
\hline \multirow{2}{*}{ Cosmetologists } & \multicolumn{3}{c}{ Regulation Intensity } & \multirow{2}{*}{ Excluded } \\
& Low & Medium & High & \\
\hline Hours Requirement & 1,130 & 1,505 & 1,988 & $/$ \\
Population Personal Income per Capita $(2010 \$)$ & 44,528 & 38,244 & 34,172 & 38,745 \\
SBSI* & 42.95 & 42.53 & 42.32 & 42.49 \\
Price $(2010 \$)$ & 34.26 & 32.92 & 26.35 & 31.29 \\
Practitioners/100,000 people** & 349.71 & 339.76 & 317.00 & 313.93 \\
Weekly Hours Worked*** & 34.27 & 34.66 & 34.29 & 34.33 \\
Age*** & 40.11 & 39.62 & 38.27 & 39.08 \\
\hline \multicolumn{1}{c}{ Number of States } & 5 & 19 & 8 & 19 \\
\hline \hline
\end{tabular}

Notes: Low hours requirement states are those with fewer than 1,500 hundred hours required, medium hours requirement states those with 1,500 hundred to less than 1,800 hours required, and high hours requirement states those with 1,800 hours or greater required. "Excluded" denotes states excluded from the analyses, mostly because of changes in their hours requirement over the 1981-2010 period. * The SBSI index, which varies only across states, is designed to take into account major state-level costs imposed on businesses; the greater the value, the greater the costs. In the sample, the index ranges from 24.9 (South Dakota) to 68.2 (D.C.). ${ }^{* *}$ Calculated from the County Business Patterns and Nonemployer Statistics for 1999-2010. *** Averaged over cosmetologists in the ACS data. 


\section{Appendix E - OLS Regression Results: Excluded States}

\begin{tabular}{lc}
\hline \hline & Indicator for Excluded States \\
\hline Log(Practitioners per Capita) & Cosmetology \\
\hline Log(Price) (2010 \$) & -0.411 \\
& $(0.293)$ \\
Log(Mean Personal Income) (2010 \$) & -0.046 \\
& $(0.458)$ \\
Log (Population) & -0.311 \\
& $(0.823)$ \\
Population: Males (Fraction) & 0.473 \\
Population: African Americans (Fraction) & $(0.345)$ \\
Population: Other Race (Fraction) & 8.782 \\
& $(26.254)$ \\
Population: Age 14 and Younger (Fraction) & -0.121 \\
Population: Age 65 and Older (Fraction) & $(0.805)$ \\
Population: At Least High School Diploma (Fraction) & 0.369 \\
Population: Unemployed (Fraction) & $(0.762)$ \\
Geographic Area (Square Miles) & -9.722 \\
SBSI & $(7.331)$ \\
& -9.633 \\
\hline \hline & $(5.978)$ \\
& 3.576 \\
& $(2.192)$ \\
& 0.170 \\
& $(1.702)$ \\
& 0.022 \\
& $(0.121)$ \\
& 0.001 \\
& $(0.009)$ \\
\hline
\end{tabular}

Notes: Standard errors are clustered by state. ${ }^{* * *}, * *$, and * indicate statistical significance at the $1 \%, 5 \%$, and $10 \%$ level. The dependent variable is an indicator denoting 19 states that were excluded from the analyses, mostly because of changes in their licensing regulation. The demographic variables describe a state population. Price information not having been collected for some years in some states, the number of observations is smaller than 663 (13 years times 50 states and D.C.). 